\title{
СИСТЕМНАЯ КОНФИГУРАЦИЯ \\ БЕЛОРУССКОЙ ЭКОНОМИЧЕСКОЙ МОДЕЛИ
}

\author{
Л.П. ВАСЮЧЕНОК
}

к.э.н., доцент кафедры «Экономика и право»

Белорусского национального технического университета

\begin{abstract}
Аннотация
Статья посвящена исследованию конфигурации белорусской экономической модели. Показано, что наииональная экономическая модель - это способ производства и распределения рент, поддерживающий единство партнерской организащии наиболее влиятельных субъектов (элиты) и служащий эталоном для воспроизведения всеми участниками экономических отнотений в стране. Сформулирован принцип извлечения ренты в белорусской экономической модели: увеличение физического объема производства при частичном возмещении издержек использования видов капитала, не имеющих в республике альтернативной денежной оценки. Аргументирована функииональность модели, которая, несмотря на всю ограниченность, обеспечивает поддержание устойчивых структурных параметров белоруской экономики.
\end{abstract}

\section{Abstract}

The article investigates the configuration of the Belarusian economic model. Shown that national economic model - it is a method of production and distribution of rents that supports unity of partner organization of the most influential subjects (elite). This method becomes the standard for playing all participants of economic relations in the country. The principle of the rent-seeking in the Belarusian economic model: an increase of the physical volume of production at the partial cost recovery of using capital types that do not have the alternative monetary assessment in the country. Argued the functionality of the model, which, despite the limitations, maintains stable structural parameters of the Belarusian economy.

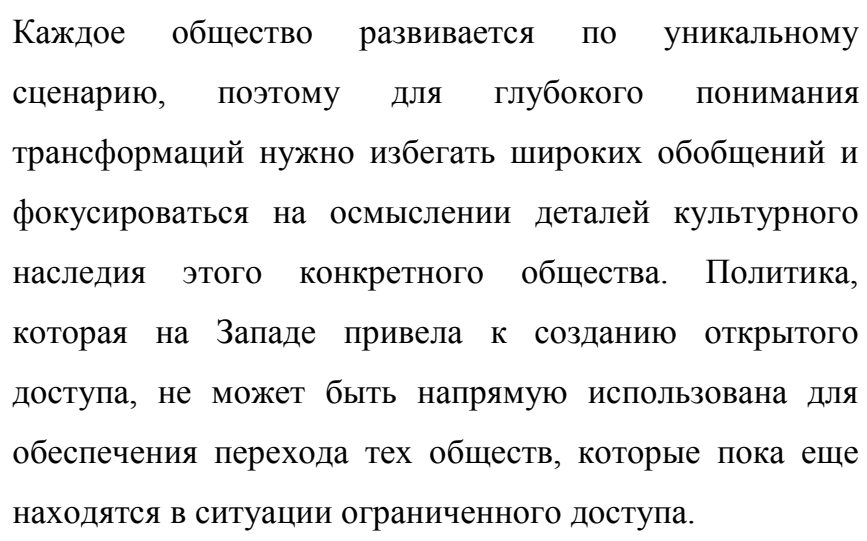

Норт Д., Уоллис Д., Вайнгаст Б. [1] 
Термин «страновая или национальная модель экономики» был введен в научный оборот относительно недавно, в последней четверти XX века. Понятие появилось как форма осмысления реально происходящих процессов синтеза универсальных принципов спонтанного рыночного хозяйства и сознательного целенаправленного воздействия на национальную экономику как единое целое, субъектом которого стало государство. Экономическую картину мира по признаку взаимодействия государства и рынка оказалось невозможно понять без некоторой типологизации национальных примеров такого взаимодействия, для чего и было использовано понятие национальная модель экономики.

\section{РЕЗУЛЬТАТЫ И ИХ ОБСУЖДЕНИЕ}

Этимология отобранного экономическим сознанием современного общества термина «модель» задает исходную точку анализа. Его общее прототипическое значение - что-либо, служащее образцом для чего-либо. Термин происходит от итальянского «modello», от латинского «modulus» - «мера (которой измеряют), мелодия, модуль», в свою очередь производного от «modus» - «мера, положение, предел». Использоваться начал с XVI века, в русский язык был введен Петром I. Большая Советская Энциклопедия определяет модель следующим образом. 1) Образец (эталон, стандарт) для массового изготовления какого-либо изделия или конструкции; тип, марка изделия. 2) Изделие (из легкообрабатываемого материала), с которого снимается форма для воспроизведения (напр., посредством литья) в другом материале; разновидности таких моделей - лекала, шаблоны, плазы. 3) Позирующий художнику натурщик или изображаемые предметы («натура»). 4) Устройство, воспроизводящее, имитирующее строение и действие какоголибо др. («моделируемого») устройства в научных, производственных (при испытаниях) или спортивных (см. Моделизм спортивный) целях .5) В широком смысле - любой образ, аналог (мысленный или условный: изображение, описание, схема, чертеж, график, план, карта и т. п.) какого-либо объекта, процесса или явления («оригинала» данной модели), используемый в качестве его «заместителя», «представителя» (см. Моделирование). 6) В математике и логике моделью какой-либо системы аксиом называют любую совокупность (абстрактных) объектов, свойства которых и отношения между которыми удовлетворяют данным аксиомам, служащим тем самым совместным (неявным) определением такой совокупности. 7) Модель в языкознании абстрактное понятие эталона или образца какой-либо системы (фонологической, грамматической и т. п.), представление самых общих характеристик какого-либо языкового явления; общая схема описания системы языка или какой-либо его подсистемы [2]. К экономическим реалиям применяются в основном две трактовки: модель как схематичное описание какого-либо явления или процесса в обществе - ближе к математической и логической формулировке, и как образец, служащий эталоном для воспроизведения. Если во втором случае целеполагающая роль модели 
очевидна, то в первом она тоже присутствует, хотя в скрытой форме - в форме соответствия заданным аксиомам, служащим совместным неявным определителем единства элементов модели.

Страновая (национальная) модель экономического развития - это совокупность элементов, формирующих целостность национального хозяйства, и механизм, обеспечивающий тесную связь и взаимодействие этих элементов. Понятие страновой модели используется в случае, если социально-экономическое и политическое развитие того или иного национального государства в течение достаточно длительного периода демонстрирует стабильность ключевых nараметров, заложенных в основу модели. Если воспроизводство этих параметров нарушается, можно ожидать либо частичную модификацию модели, либо ее полную трансформацию. Посредством отбора качественных и количественных параметров, задающих целостность экономики, модель определяет источники и механизмы, мотивацию и результаты экономической деятельности социально-экономический облик страны.

Целостность национального хозяйства не возникает автоматически. Исторически и логически она создается партнерской организацией ${ }^{1}$ наиболее влиятельных субъектов (элиты), принимающей, в конечном счете, форму организации организаций - национального государства. Поскольку коалиция наиболее влиятельных субъектов является партнерской организацией - ее члены не зависят друг от друга, неизбежность целостности не гарантирована. Целостность возникает из создания и балансирования специальных интересов у этих влиятельных субъектов в рамках особого процесса, названного Д. Нортом, Дж. Уоллисом и Б. Вайнгастом в работе «Насилие и социальные порядки» процессом создания ренты ${ }^{2}$. Поскольку позиции, привилегии и ренты субъектов в господствующей коалиции зависят от ограничения доступа к ним остальных субъектов, обеспечиваемого продолжающимся существованием коалиции, все они имеют стимулы поддерживать коалицию и способствовать ее сохранению. Создают и распределяют ренту среди членов коалиции организации элиты. Поэтому одним из наиболее ценных источников ренты для элиты является привилегия создания организаций, которые будут пользоваться поддержкой государства. Изобретая способы поддержки контрактных организаций, и распространяя привилегию формирования этих организаций на своих членов, господствующая коалиция создает способ производства и распределения рент внутри коалиции, а также надежный способ объединения и дисциплинирования субъектов, поскольку их организации зависят от сторонней поддержки коалиции. Способ производства и распределения рент, поддерживающий единство партнерской организации наиболее влиятельных субъектов, или, иными словами, способ создания и установления баланса интересов для поддержания единства правящей коалиции и составляет национальную экономическую модель как эталон для воспроизведения всеми участниками

\footnotetext{
${ }^{1}$ Партнерские организации характеризуются исполняющимися без внешнего вмешательства и содержащими в себе стимулы соглашениями ее членов. Эти организации не нуждаются в существовании третьей стороны, которая принуждала бы к исполнению внутренних соглашений. Кооперация членов партнерской организации должна быть в каждый момент времени совместима со стимулами для всех членов.

2 Рента - это отдача от экономического актива, превышающая отдачу, которая может быть получена от лучшего альтернативного использования этого актива.
} 
экономических отношений в стране, служащий совместным неявным определителем единства элементов модели.

Так как создание интересов поддержания целостности национальной экономики у наиболее влиятельных субъектов и установление их баланса составляет суть национальной экономической модели, имеет смысл кратко остановиться на определении интереса. Латинские корни слова «interresse» приводят к трактовке - «быть между», от взаимодействия «inter-между» + «esse-быть или сущность», - нечто между самостоятельными сущностями. Как коммерческий и правовой термин возник в средние века (XIV-XV -становление товарного хозяйства в Европе) и означал возмещение ущерба. Английские словари трактуют исходное понятие как законные права требования, компенсацию за утрату, законное беспокойство персоны о чем-либо, законная озабоченность. В XVIII веке слово стало использоваться в контексте выгоды, пользы, дохода. В значении «curiosity - любопытство» впервые зафиксировано тоже в XVIII. В русский язык слово вошло в петровскую эпоху. Согласно словарю Брокгауза и Эфрона издания 1898 г., «интерес обозначает выгоду или пользу отдельного лица или известной совокупности лиц, противополагаемые выгоде и пользе других лиц» [3].

Положение об определяющей роли интереса (именно экономического) среди мотивов человеческой деятельности было выдвинуто впервые французскими материалистами XVIII века и представителями английской классической политической экономии. И произошло это не случайно. В парадигме активно развивающегося товарного хозяйства люди связаны между собой не природными отношениями или традициями, не этическими нормами или чувствами, а искусственным технологическим разделением труда ${ }^{3}$ и текущими между ними как производителями и потребителями товаров потоками потребительных и меновых стоимостей. При указанной диспозиции субъектов экономических отношений главное, что их связывает - это абстрактная выгода - приращение универсального эквивалента искусственно структурированных

\footnotetext{
3 Техника - общее название различных приспособлений, механизмов и устройств, не существующих в природе и изготовляемых человеком. Технология - способ преобразования исходных сырья, полуфабрикатов или данных в конечный продукт с заданными свойствами. Если обратиться к самому определению термина технология, к его изначальному значению (техно — мастерство, искусство; логос — наука), то цель технологии заключается в том, чтобы разложить на составляющие элементы процесс достижения какоголибо результата. «...мы хотели бы объяснить определение понятие технологии, которое активно используем в работе. Производство индустриального типа - это прежде всего применение искусственных материалов и орудий труда, и именно они задают последовательность и методы собственного использования (хотя и в широких пределах, ...). Поэтому под технологиями мы понимаем совокупность технической системы, приемов ее применения, знаний и опыта (профессий, социальных ролей), необходимых для ее эксплуатации. Техническая система, ..., представляет собой инструменты или, точнее, средства производства, используемые для превращения исходного материала в продукт, и включает: (1) орудия труда, (2) передаточный механизм, (3) источник энергии, (4) коммуникационные устройства, (5) вспомогательные устройства, (6) контрольно-логические элементы. Такое определение избавляет нас от необходимости делать оговорки в процессе употребления категории технологий об объективном, предзаданном технической системой характере приемов и методов использования средств и предметов производства, и в то же время указывать на субъективный элемент технологий - человека, выполняющего эти приемы. Наше определение объединяет человека и технические элементы производственного комплекса, фактически уже показывает их неразрывную связь в производственном ядре каждой организации (а следовательно, и всего общества) и позволяет протянуть логическую нить от производства, понимаемого как физическая трансформация ресурсов в продукт, к социальным отношениям, в которых оно протекает»[4].
} 
полезностей - интерес. Акцент на интересы в мотивации субъектов указывает на доминирование товарного хозяйства в экономической системе, а создание и балансирование интересов (как и дизайн потребностей) становится естественным ее свойством.

Представители марксистского обществоведения использовали категорию «экономический интерес» в духе классической политической экономии, подчеркивая материальный характер классовых интересов. Энгельс писал, что экономические отношения каждого данного общества проявляются прежде всего как интересы. Марксистская постановка проблемы интересов свидетельствует, во-первых, о марксизме как о теории товарного хозяйства, несмотря на заявленную позицию критики политической экономии, а во-вторых, о теоретическом замыкании интереса на одну сторону товара - потребительную стоимость, отождествленную в марксистской трактовке товара с физическими - «материальными» - свойствами производимых и обмениваемых вещей.

В современной экономической теории понятие экономического интереса широко применяют, связывая его с понятиями «выгода», «выбор», «максимизация», «рациональность». Основные подходы сводятся к следующему: люди, как правило, совершают те действия, которые, по их мнению, должны принести им наибольшую выгоду. Но утверждения экономистов о том, что индивиды рациональны и стремятся к тому, что они считают своими интересами, вызывают возмущение в остальных общественных науках. Тем не менее, осознание того факта, что исследователи общества имеют ограниченное представление о том, что происходит внутри людей - что их мотивирует, радует, злит и пугает, проникает и в экономическую теорию. Свидетельством этого может служить разделяемое нами суждение авторов названной выше книги «Насилие и социальные порядки»: «Интересы возникают из взаимодействия предпочтений, альтернатив и каузальных убеждений. То, что индивиды считают своими интересами, является сложной смесью их предпочтений в отномении различных результатов, альтернатив, $c$ которыми они сталкиваются, а также их убеждений о том, как их действия затронут мир вокруг них. (Курсив мой - Л.П. Васюченок.) Люди осуществляют действия преднамеренно; на основе своего выбора они пытаются достичь наилучших результатов в условиях ограниченности ресурсов, но их поведение в значительной степени зависит от их представлений о том, как на самом деле работает окружающий их мир. Поскольку мир слишком сложен для того, чтобы человек смог его полностью понять, ни одна из систем убеждений не может быть полностью точным описанием мира вокруг нас» [5]. Принципиальным отличием предложенного понимания интереса от классического и от марксистского является акцент на оценочном характере выгод и потерь субъектов в экономическом взаимодействии и ведущей роли в этой оценке каузальных убеждений (beliefs) субъектов - системы их представлений о мире.

И еще об одном термине, используемом в статье - о конфигурации. Согласно словарям, в истории науки конфигурация - (от позднелатинского configuratio - придание формы расположение) внешний вид, очертание, взаимное расположение, соотношение некоторых предметов. Применительно к экономической модели этот термин означает не только устойчивое 
соотношение элементов, их взаимное расположение, стабильность параметров объекта, но активную роль субъекта, создающего нужную конфигурацию. Так же как конфигурация программного обеспечения - это совокупность настроек программы, задаваемая пользователем, конфигурация экономической модели - это взаимное расположение элементов экономической системы, создаваемое элитой для производства ренты в рамках партнерских организаций наиболее влиятельных субъектов в предлагаемых исторических условиях и в соответствии с beliefs каузальными убеждениями этих субъектов. Сама постановка проблемы модели хозяйства как формы проявления универсальных по определению законов эквивалентного рыночного обмена в конкретных идиосинкразических, амбивалентных природных, технологических, национальных, исторических, культурных условиях страны стала актуальной в парадигме «победно шествующего» товарного хозяйства. Там, где нет товарного принципа универсальной эквивалентности в отношениях людей, не может быть и образца для воплощения, нет модели.

Технологическое разделение труда в белорусской экономике, соответствующие ему организации субъектов и господствующие каузальные убеждения в период формирования национальной экономической модели были обусловлены позициями, сложившимися после распада СССР. В качестве точки начала отсчета возьмем 1995 год, так как к этому моменту «советское наследие» проявилось в ценах и материально-вещественных пропорциях в народном хозяйстве республики в новых условиях. В объеме выпуска экономики в 1995 году 43\% составляла продукция промышленности, 16,6\% продукция сельского хозяйства, 5,7\% - строительства, 33,8\% производство услуг, среди которых транспорт и торговля производили по 6,5\% продукции каждая, чуть меньше - от 3 до 2\% коммунальное хозяйство, жилищное хозяйство, образование, здравоохранение и кредитование. Доля промежуточного потребления в выпуске составляла по народному хозяйству 64,5\%, по промышленности $-76,5 \%$, по сельскому хозяйству - 73,2\%, по строительству - 62\%, по производству услуг - 48,5\%. Доля этих же отраслей в промежуточном потреблении в экономике в целом была соответственно 51\% для промышленности, 19\% для сельского хозяйства, 5,5\% для строительства и 24\% для производства услуг. Доля в ВВП составила: промышленности - 28\%, сельского хозяйства $-12,5 \%$, строительства $-6,5 \%$, услуг $51,6 \%$ в том числе, транспорта и торговли по 10,6 и 9,2\%, коммунального и жилищного хозяйства $-8,9 \%$, от 5,9 до $3,4 \%$ была доля образования, кредитования и здравоохранения (каждого). Самыми масштабными отраслями промышленности в 1995 году были электроэнергетика (13,8\% объема выпуска промышленности), химия и нефтехимия (14,3\%), машиностроение и металлообработка $(23,3 \%)$, пищевая промышленность $(17 \%)$, легкая промышленность (8\%), топливная, лесная и промышленность стройматериалов производили по 4$5 \%$ выпуска[6].

Наиболее мощные экономические организации так же существовали в этот период в промышленности - 1937 предприятий со среднесписочной численностью персонала 1175 тыс. человек, причем около 500 тыс. человек работало на 420 предприятиях машиностроительной отрасли, более 90 тыс. на 52 предприятиях химии и нефтехимии, более 100 тыс. на 210 
предприятиях лесной, 184 тыс. на 422 предприятиях легкой и 107 тыс. на 422 предприятиях пищевой промышленности[7].

Расходовался ВВП в 1995 году следующим образом: 50\% шло на потребление домохозяйств, около $22 \%$ на государственное потребление, более $7 \%$ - на некоммерческие организации, обслуживающие домашние хозяйства, $25 \%$ на валовое накопление и 4,7\% составило отрицательное сальдо внешней торговли. Налоги на продукты и импорт составляли $12,8 \%$ ВВП, субсидии - около 3\%. В государственном бюджете аккумулировалось 30\% ВВП, расходовалось более $32 \%, 21 \%$ расходов бюджета шло на народное хозяйство, 42,8\% на социально-культурные мероприятия, $10 \%$ на госуправление. Бюджет социального страхования расходовал еще более $10 \%$ ВВП. Кредитование банками отраслей народного хозяйства и населения выглядело следующим образом. В остатках ссуд на конец года краткосрочное кредитование занимало 87\%; 23\% из этой суммы получала промышленность, $6 \%$ сельское хозяйство, $3 \%$ строительство, $14,5 \%$ - торговля. Почти $80 \%$ долгосрочных ссуд было предоставлено государственным организациям и $20 \%$ населению[8]. Индекс потребительских цен в 1995 году к декабрю предыдущего года составил 3,4 раза, индекс цен производителей промышленной продукции - 2,4 раза, индексы цен на сельхозпродукцию варьировались в диапазоне от 4 до 9 раз для разных видов. Потребление основных продуктов питания на душу населения в год сократилось по сравнению с 1990 годом по всем видам кроме картофеля и овощей, обеспеченность предметами длительного пользования так же стала ниже по всей группе за исключением часов и автомобилей, правда, последних без учета морального и физического износа.

В структуре производства преобладали отрасли, характеризующиеся высокой зависимостью от поставок промежуточной продукции из-за пределов республики и значительной долей импортной составляющей в цене собственной готовой продукции. Проведенные белорусскими исследователями расчеты показали, что в систему межотраслевых связей внутри республики были и остаются наименее интегрированными нефтяная промышленность, черная металлургия, машиностроение и металлообработка, цветная металлургия. Несколько неожиданной оказалась невысокая включенность так же пищевой промышленности и строительства. Наибольшая включенность в национальную экономику зафиксирована у легкой промышленности, лесной, деревообрабатывающей и целлюлозной, промышленности стройматериалов, некоторых отраслей сферы услуг: торговли, информационного обслуживания, образования и здравоохранения, транспорта и связи. Отрасли, создававшие в экономике большую долю добавленной стоимости и объема выпуска, технологически обособлены от национальной экономики и ориентированы в производстве на использование импортного сырья, а в их затратах отечественной продукции доминирует продукция той же отрасли [9].

Чтобы обеспечить центростремительные, а не центробежные интересы наиболее крупных организованных субъектов белорусской экономики, а таковыми после роспуска КПСС оказались крупные (валообразующие) предприятия, белорусскому государству необходимо было предложить им ресурсы большие, чем получаемые в сложившихся технологических цепочках 
взаимодействий с партнерами вне республики. Для обеспечения целостности национальной экономики нужно было создать у валообразующих предприятий заинтересованность в организации и поддержании коалиции в виде привилегий членов коалиции в доступе к ресурсам. Условием получения привилегированного доступа к ресурсам должна служить организащия извлечения ренты из поступивших в распоряжение ресурсов и ее распределение между группами интересов в коалиции в соответствии с ролью в поддержании целостности. Перефразируя Д. Норта можно сказать, что систематическое создание ренты при помощи ограниченного доступа это не просто средство набить карманы членов господствующей коалиции, а важнейшее средство поддержания целостности национальной экономики.

Согласно сформулированным выше теоретическим положениям при наборе альтернатив в рамках существующих условий направление развития зависит от ментальных конструкций способов восприятия и анализа информации, выработки решений, от идеологии субъектов, получивших политическую власть как главный инструмент строительства новой модели. Решающую роль в выборе белорусской элитой способа извлечения ренты сыграло влияние норм и практик экономического поведения субъектов, существовавших в советской системе. Принцип установления отношений в виде персонифицированных контрактов (формальных и неформальных) в рамках советской партийной иерархии был принят в качестве базового при построении экономической модели в Беларуси. Весь объем прав собственности в ней закреплен за вертикалью власти, уровням государственного управления и субъектам хозяйствования делегированы ограниченные права контроля, частная собственность легализована на условиях, согласованных с вертикалью. Целью создания вертикали провозглашалось повышение управляемости экономики, реально она была призвана обеспечить более благоприятные контрактные отношения белорусских предприятий, включенных в вертикаль, с группами влияния на сегментированных российских рынках. Вертикаль выводит своих субъектов хозяйствования на более высокие уровни контрактных отношений, минимизируя транзакционные и производственные издержки. Установление в конце XX - начале XXI века главой вертикали благоприятных для белорусских предприятий личных неформальных отношений с руководством России и ее группами влияния - яркий пример институционального наследования, пример эффективности норм и практик персональных согласований в постсоветских России и Беларуси [10].

Поскольку лучшие условия работы белорусских предприятий - результат усилий вертикали, эта организация наиболее влиятельных субъектов белорусской экономики заинтересована в контроле и распоряжении полезными эффектами от использования оговоренных условий. Чтобы уловить распределенные по экономике неочевидные полезные эффекты сложных объектов (предприятий), был создан разветвленный бюрократический механизм регулирования хозяйственной деятельности и мощная система контрольных органов. Государственное планирование и прогнозирование, регламентация ценообразования, трудовых отношений, внешнеэкономической деятельности, лицензирование и сертификация, налоговая, бюджетная, 
денежно-кредитная политика выстроены с целью контроля над перераспределением полезных эффектов. На предмет соответствия принципу построения отношений в виде персонифицированных формальных и неформальных соглашений субъектов, расположенных на разных уровнях вертикали власти, прошли отбор все отношения, сложилась белорусская национальная экономическая модель как специфическая целостная система отношений, адекватная принятым в наследство базовым институтам.

Создание ренты предполагает извлечение из ресурсов большей отдачи, чем затраты на их получение, то есть, рента возникает тогда, когда отдача ресурса для данного субъекта больше, чем оценка отдачи этого ресурса всеми остальными субъектами. Решение таким образом поставленной проблемы лежит в двух плоскостях: в увеличении полезного эффекта работы ресурса для данного субъекта и в снижении его издержек на использование ресурса. Коалиция господствующих субъектов в республике избрала в качестве способа извлечения ренты увеличение физического объема производства при частичном возмещении издержек использования видов капитала, не имеющих в стране альтернативной денежной оценки, соответствующей рыночным принципам. К таким видам капитала в республике относятся основные фонды предприятий, человеческий капитал, природные ресурсы, включая землю, предпринимательские способности, интеллектуальный капитал. Достигается отсутствие альтернативной денежной оценки указанных видов капитала ограничением доступа к ним субъектов без согласования с господствующей коалицией.

Так как ряд экономических ресурсов не имеют в белорусской модели альтернативной денежной оценки, определить степень возмещения их использования на основе статистической информации, отражающей стоимостную оценку текущих затрат и результатов, например, ВВП, системы национальных счетов, структуры затрат на выпуск продукции, финансовых результатов работы организаций и т.д., сложно, но по некоторым параметрам возможно. Попытаемся дать количественную оценку возмещения затрат основного капитала и возмещения затрат на воспроизводство населения как видов ресурсов, имеющих некоторую денежную оценку и натурально-вещественную характеристику.

Возмещение основного капитала отражается статистикой, в частности, в виде амортизационных отчислений и доли накопления в ВВП. Доля амортизации в структуре затрат на производство промышленной продукции в 1990 году составляла 9,4\%, в $2000-3,6 \%$, в $2010-$ 3,8\%. В других отраслях народного хозяйства в течение указанного десятилетия она также была достаточно стабильна: в сельском хозяйстве колебалась между 7,5\% и 9,3\%, в транспорте - между 11,5 и 13,4\%, в строительстве - между 2,8 и 2,9\%, только связь демонстрировала устойчивый рост доли амортизации с 14,8\% в 2000 году до 23,1\% в 2010 году. По народному хозяйству в целом она составляла от 4,6 до 6\% в течение десятилетия. Валовое накопление основного капитала в структуре расходов ВВП составляло в 1990 году 26,6\%, в 2000 году - 25,6\%, в 2010- 39,2\% [11]. Доля амортизации в валовом накоплении может быть определена исходя из доли амортизации в ВВП. В промышленности в 1990 году она составила по установленным нормам более 20\%, а в 
2010 году - около 16\% произведенной добавленной стоимости. Если долю амортизации в структуре затрат на производство промышленной продукции в 2010 оценить в таком же размере, как в 1990 году, а для такой экстраполяции есть серьезные основания, в добавленной стоимости промышленности она должна была бы составить не менее 38\%.(Рассчитано автором по[12]). С учетом того, что на все валовое накопление основного капитала было потрачено чуть более $39 \%$ ВВП, причем около 14\% ВВП - это отрицательный чистый экспорт, можно констатировать, что начисление амортизации по существующим правилам не обеспечивает простое воспроизводство производственного аппарата на советском уровне. Тем не менее, указанная практика позволяет государству и предприятиям получать ресурсы в виде прибыли и налогов для поддержания целостности национальной экономики и обеспечения баланса интересов основных организованных субъектов.

Система оплаты труда в республике фиксирует нижнюю (минимальный потребительский бюджет, тарифная ставка первого разряда, минимальная заработная плата) и верхнюю границы заработной платы, ее дифференциацию в указанных рамках, включая среднюю зарплату как целевой показатель. В течение всего десятилетия заработная плата основной массы занятых колебалась в пределах 2-3 минимальных потребительских бюджетов. В 2010 году 5,4\% домохозяйств располагали ресурсами ниже минимального потребительского бюджета, около 45\% - от 1 до 2, около 70\% - от 1 до 3 бюджетов. Поддержание заработной платы в пределах 2-3 минимальных потребительских бюджетов обеспечивает семье ресурсы для рождения одного ребенка. Рождение второго автоматически отправляет семью в разряд низко обеспеченных, ибо доход в 2-3 бюджета должен распределяться на 4 человек. Суммарный коэффициент рождаемости $1,2-1,5$ в течение десятилетия отражает это положение и свидетельствует об отсутствии простого воспроизводства населения республики. Доля заработной платы в структуре затрат была достаточно устойчивой, имела слабую тенденцию к возрастанию в 2009-2010 годах, но в 2011 году снизилась. Доля валового потребления в ВВП снизилась с 77\% в 2000 году до 72\% в 2010, а доля потребления домохозяйств колебалась в пределах 50-55\%. При уменьшении численности населения можно было бы говорить о росте качества человеческого капитала, но снизилась и доля образования (в ВВП с 4,5\% до 4\%, в расходах консолидированного бюджета - с 47,4\% до 38,8\%), увеличилась заболеваемость населения, особенно детей [13].

Технологическая и отраслевая структура инвестиций в основной капитал в течение последнего десятилетия и даже последних 15 лет не претерпела существенных изменений. Увеличилась доля инвестиций в сельское хозяйство, строительство и торговлю, чуть снизилась доля промышленности, транспорта, образования и здравоохранения. Доли жилищного строительства и жилищно-коммунального хозяйства остались прежними. Подтверждается неизменность структурных параметров белоруской экономики индексами физического объема основных средств по отраслям экономики, которые в течение 10 лет для большинства отраслей колебались вокруг 102\% [14]. Извлекаемая рента перераспределялась между организованными субъектами (ведомствами и регионами, отраслями и областями) в соответствии с их долей в 
фондах, объемах выпуска и численности занятых. Поэтому отраслевая (по производимым и потребляемым потребительным стоимостям) и воспроизводственная (по произведенной и потребленной стоимости) структура экономики республики за десятилетие практически не изменилась. Например, основную долю продукции промышленности как производили, так и производят отрасли топливной (17,6\%), химической $(13,3 \%)$, пищевой промышленности $(17,9 \%)$, машиностроение и металлообработка (22\%). Вклад электроэнергетики, промышленности стройматериалов, лесной, деревообрабатывающей и целлюлозно-бумажной, a также легкой промышленности - от 7 до 4\% каждой (в сумме около 20) \% выпуска. Доли отраслей сохраняются в ВВП в течение десятилетия с незначительными колебаниями.

А вот структура источников инвестиций стала иной. Доля кредитов банков, причем местных, выросла более чем в 2 раза, доля бюджета и собственных средств предприятий снизилась на треть каждая, доля населения осталась той же. Кредиты в инвестициях в 2010 году сравнялись с собственными средствами предприятий и превысили бюджетное финансирование. Это означает, что источником экономического роста в республике на треть стало создание кредита, который был направлен в отрасли со старой продуктивностью факторов, не способной возместить возросшую их цену. Окупаемость инвестиций упала (за указанный период предельный коэффициент капиталоотдачи, рассчитываемый путем деления темпа роста ВВП на отношение инвестиций к ВВП, снизился с 4,5 до 0,5) [15].

Недовложение амортизации и затрат на воспроизводство рабочей силы в цену производимой продукции не имели существенного значения для экономики, пока были резервы производственных мощностей и избыток предложения труда. Производственные мощности белорусских предприятий, согласно данным официальной статистики, в 2011 году использовались на 70\%. В лучшие годы в американской экономике коэффициент загрузки производственных мощностей доходил до $83 \%$, что позволяет предположить некоторые ресурсы роста. Но степень износа основных фондов в республике составляет около $50 \%$, а средний возраст производственного оборудования в промышленности - около 20 лет, тогда как средний срок работы американского - 6-7 лет. Поэтому увеличение загрузки оборудования в республике вряд ли возможно без дополнительных вложений. Численность населения в трудоспособном возрасте, возраставшая в предшествующее десятилетие, начала снижаться, и тенденция эта будет устойчивой и долгосрочной. Внешние источники обеспечения существующего баланса интересов ресурсами сокращаются вследствие роста цены заимствований и углубляющейся интеграции основного внешнеэкономического партнера в мировую экономику.

Источником поддержания целостности модели, не изменяющим принципов еe функционирования, может служить точечная приватизация, проводимая на принципах индивидуального включения новых игроков в систему извлечения ренты, не нарушающая сложившегося баланса интересов. Выработка персональных условий работы новых субъектов в белорусской экономике делает приватизацию в стране медленным и затратным процессом и 
предполагает не продажу объектов любому желающему на общих принципах, а заключение особых договоров с крупными организованными структурами.

Взаимодействие между элементами (организациями производителей, потребителей и регуляторов в экономике - предприятиями, домохозяйствами, государственными органами и организациями) и компонентами (отраслями и областями, ведомствами и регионами) белорусской экономической модели обеспечивают рынки. Общей чертой их функционирования в данной модели является неполнота и сегментация. Регламентированный государством по ценам и товарному наполнению рынок предметов потребления характеризуется высокой долей продовольствия, более низкими ценами на продукты, чем на непродовольственные товары, меньшей долей услуг и более низкими ценами на них, преобладающим предложением товаров с низкой эластичностью спроса по доходу. Рынок труда характеризуется высоким спросом на неквалифицированный дешевый труд, низкой ценой труда, низкой трудовой мобильностью, возложением издержек рыночного поведения работника на него самого (фактическое отсутствие страхования по безработице), низким спросом и предложением дорожающего высококвалифицированного труда, снижением стимулов к подготовке квалифицированных специалистов, слабыми стимулами к рациональному использованию труда и внедрению эффективных трудосберегающих технологий. Рынок средств труда характеризуется ограниченным спросом и предложением новых капитальных благ с высокой ценой и высокой эффективностью, преобладающим оборотом товаров с низкой эластичностью по доходам, процедурами торгов, затрудняющих оценку качества при покупке оборудования, что превращает рынок средств труда в республике в «рынок лимонов» в терминологии Акерлофа, приводящий к снижению среднего качества товаров и размеров рынка. Рынок предметов труда - ключевой в системе белорусских рынков, самый масштабный и самый регулируемый. Все промежуточное потребление в экономике - 2/3 объема выпуска в стране - обращается на рынке предметов труда. В дополнение к общим чертам сырьевых рынков - их высокой монополизации и высокой волатильности, белорусские рынки предметов труда характеризуются существенной сегментацией и закрытостью. В предметах труда на рынках республики, не располагающей богатыми природными ресурсами, преобладают импортное сырье и продукты его первичной переработки, поставляемые на специфических условиях.

\section{ВЫВОДЫ}

Краткий анализ конфигурации белорусской экономической модели позволяет сформулировать некоторые выводы, и один из наиболее важных - следующий: белорусская экономическая модель - не болезнь и не отклонение от глобальных тенденций. У нее есть своя собственная логика, и она функциональна. Она не слишком устойчива к шокам, не располагает большими резервами, но способна изыскивать ресурсы для выполнения как минимум двух основных функций любого общества: поддержания стабильности и поддержания порядка. С точки 
зрения рыночных норм и ценностей (порядков открытого доступа) эта модель представляется ограниченной, но эта ограниченность является главным инструментом поддержания общности.

Второй вывод касается проблемы развития, которое согласно предлагаемому концептуальному подходу возможно как развитие в рамках существующей модели и как переход от социального порядка ограниченного доступа к порядку доступа открытого. Большая часть рекомендаций ученых-экономистов, международных организаций, политиков - это предложения по стимулированию перехода. Однако динамика социально-экономических изменений в белорусской модели — это динамика именно порядка ограниченного доступа, это развитие в рамках существующей модели. Беларусь, как и большинство стран, за несколькими исключениями, так и не достигла пороговых условий перехода к порядку открытого доступа [16]. Элиты в таких странах не могут начать выстраивать стабильные отношения друг с другом посредством обезличенных институтов при решении важнейших вопросов, касающихся экономики и политики. Применительно к ним советы начать переход оказываются неуместными. Установление хорошо прописанных прав элит в таких условиях бесперспективно. Перенесение безличных рыночных институтов в модели, основанные на персонифицированных контрактах коалиции господствующих субъектов, само по себе не может привести к политическому и экономическому развитию. Если новые нормы и правила извлечения ренты навязываются элите и обществу под международным или внутренним давлением и если при этом они не соответствуют существующим представлениям об экономических, политических, социальных и культурных системах, то новые институты почти наверняка будут работать куда хуже тех институтов, которые они замещают. Более того, если эти новые институты подрывают социально-экономические механизмы, обеспечивающие политическую стабильность, то тогда они будут неминуемо способствовать беспорядку, ввергая общество в еще более плачевное состояние.

\section{ЛИТЕРАТУРА}

1. Норт, Д. Насилие и социальные порядки. Концептуальные рамки для интерпретации письменной истории человечества/ Д. Норт, Д. Уоллис, Б.Вайнгаст / Пер. с англ. Д. Узланера, М. Маркова, Д. Раскова, А. Расковой. М.: Изд. Института Гайдара, 2011. - 480 с. [Электронный pecypc] - Режим доступа: http://lib.rus - Дата доступа: 07.05.2012.

2. Большая Советская Энциклопедия [Электронный ресурс] - Режим доступа: http://bse.scilib.com - Дата доступа: 15.06.2012.

3. Энциклопедический словарь Брокгауза и Эфрона [Электронный ресурс] - Режим доступа: http://slovari.yandex.ru - Дата доступа: 15.06.2012.

4. Белоусенко, М. В. Общая теория экономической организации: организационная эволюция индустриальной экономики / М. Белоусенко // Донецк: ДонНТУ, 2006. - 432 с.

5. Норт, Д. Насилие и социальные порядки. Концептуальные рамки для интерпретации письменной истории человечества/ Д. Норт, Д. Уоллис, Б.Вайнгаст / Пер. с англ. Д. Узланера, М. 
Маркова, Д. Раскова, А. Расковой. М.: Изд. Института Гайдара, 2011. - 480 с. [Электронный pecypc] - Режим доступа: http://lib.rus - Дата доступа: 07.05.2012.

6. Статистический ежегодник Республики Беларусь, 2011. [Электронный ресурс] - Режим доступа: http:// belstat.gov.by/homep/ru/publications/2011.php - Дата доступа: 17.11.2013.

7. Статистический ежегодник Республики Беларусь, 2011. [Электронный ресурс] - Режим доступа: http:// belstat.gov.by/homep/ru/publications/2011.php - Дата доступа: 17.11.2013.

8. Статистический ежегодник Республики Беларусь, 2011. [Электронный ресурс] - Режим доступа: http:// belstat.gov.by/homep/ru/publications/2011.php - Дата доступа: 17.11.2013.

9. Злотникова, Е. Импортоемкость и межотраслевая кооперация в белорусской экономике / Е. Злотникова // Банковский вестник. - Декабрь 2010. - № 34. - С. 27-30.

10. Васюченок, Л.П. Роль институционального наследования в формировании национальной экономической модели Беларуси / Л.П. Васюченок // Вестник Гродненского государственного университета им. Янки Купалы. Сер. 5. Экономика. - 2010. - № 2. - С. 9-13.

11. Статистический ежегодник Республики Беларусь, 2011. [Электронный ресурс] - Режим доступа: http:// belstat.gov.by/homep/ru/publications/2011.php - Дата доступа: 17.11.2013.

12. Статистический ежегодник Республики Беларусь, 2011. [Электронный ресурс] - Режим доступа: http:// belstat.gov.by/homep/ru/publications/2011.php - Дата доступа: 17.11.2013.

13. Статистический ежегодник Республики Беларусь, 2011. [Электронный ресурс] - Режим доступа: http:// belstat.gov.by/homep/ru/publications/2011.php - Дата доступа: 17.11.2013.

14. Статистический ежегодник Республики Беларусь, 2011. [Электронный ресурс] - Режим доступа: http:// belstat.gov.by/homep/ru/publications/2011.php - Дата доступа: 17.11.2013.

15. Шуанг Динг. Беларусь: Источники экономического роста в прошлом и перспективы роста в будущем [Электронный ресурс] - Режим доступа: http://www.imf.org - Дата доступа: 14.06.2013.

16. Норт, Д. Насилие и социальные порядки. Концептуальные рамки для интерпретации письменной истории человечества/ Д. Норт, Д. Уоллис, Б.Вайнгаст / Пер. с англ. Д. Узланера, М. Маркова, Д. Раскова, А. Расковой. М.: Изд. Института Гайдара, 2011. - 480 с. [Электронный pecypc] - Режим доступа: http://lib.rus - Дата доступа: 07.05.2012. 